\title{
Class/Race Polarisation in Venezuela and the Electoral Success of Hugo Chávez: a break with the past or the song remains the same?
}

\section{Barry Cannon}

To cite this article: Barry Cannon (2008) Class/Race Polarisation in Venezuela and the Electoral Success of Hugo Chávez: a break with the past or the song remains the same?, Third World Quarterly, 29:4, 731-748, DOI: 10.1080/01436590802075020

To link to this article: https://doi.org/10.1080/01436590802075020

曲 Published online: 08 May 2008.

Submit your article to this journal $\widetilde{ }$

Џ Article views: 702

Citing articles: 14 View citing articles 


\section{Class/Race Polarisation in Venezuela and the Electoral Success of Hugo Chávez: a break with the past or the song remains the same?}

\section{BARRY CANNON}

ABSTRACT Polls have repeatedly shown a class-based polarisation around Chávez, which some political science analysis on Venezuela has recognised. This paper seeks to show, however, that this class-based division needs to be placed in historical context to be fully understood. Examining Venezuelan history from the colonial to the contemporary era the paper shows, unlike most previous work on Bolivarian Venezuela, that race is an important subtext to this class-based support, and that there is indeed a correlation between class and race within the Venezuelan context. Furthermore, class and race are important positive elements in Chávez's discourse, in contrast to their negative use in opposition antiChavismo discourse. The paper briefly reviews the Chávez government's policy in tackling the class/race fissures in Venezuelan society, and concludes by asking whether these policies represent a change in the historical patterns of classism and racism within Venezuelan society or are simply reproducing past patterns.

President Chávez of Venezuela and the movement led by him has repeatedly triumphed at the ballot box since first being elected to the presidency in 1998 . In the presidential elections of 2000, the revocatory referendum of 2004 and the latest presidential election in 2006, Chávez has maintained or increased his percentage of the vote. But who is voting for Chávez in Venezuela and why?

In this article we find that Chávez's support is primarily among the poorer sections of the Venezuelan people, the popular classes, and that in Venezuela, generally speaking, class interacts with race 'in the production of inequalities'. ${ }^{1}$ This class/race interaction in Venezuela has deep roots in the country's history, and the social fissures which stem from that fusion have been repeatedly glossed over by successive governments, aiming instead to create a myth of a united Venezuela, where class and race are elided from public discourse. $^{2}$ Chávez, on the other hand, in his discourse and in his government's policies, has repeatedly drawn attention to class differences in the country, by attacking the privileged classes and favouring the popular

Barry Cannon is a post-doctoral fellow in the School of Law and Government, Dublin City University, Dublin 9, Ireland.Email: barry.cannon@dcu.ie.

ISSN 0143-6597 print/ISSN 1360-2241 online/08/040731-18 (c) 2008 Third World Quarterly DOI: $10.1080 / 01436590802075020$ 
classes - el pueblo - while also drawing attention to race issues in a number of his pronouncements.

The class/race fusion is an essential element needed to explain Chávez's continuing popularity but most political analysis has paid little attention to the impact of race on Venezuelan politics. ${ }^{3}$ This paper aims to redress this by evaluating the role of race within more widely based class divisions in the emergence of Chávez. Furthermore, and equally importantly, the paper seeks to show that race, or rather racism, is an essential, but extremely subtle, ingredient in opposition discourse rejecting Chávez and those who follow him.

The paper will examine these issues by first reviewing poll data on support for Chávez proving the class-based nature of support for him. We will then go on to provide a theoretical exploration of the complex relationship between race and class, and illustrate this by examining class- and race-based prejudice in Venezuelan history. The paper will present both quantitative data on ethnicity and refer to studies on media content in contemporary Venezuela, to illustrate the persistence and prevalence of racist discourse there. We will then go on to look at the role of class and race in the discourse of both Chávez and the opposition, showing how the former uses it positively to engage with the poorer, darker skinned majority, while the opposition uses it negatively to provoke a negative reaction to Chávez and his supporters, mostly among the middle and upper classes. Furthermore, we will review positive policy measures looking to reverse these classist and racist historical trends implemented by the Chávez government and ask if this is a genuine attempt to break from this past, or whether it is simply the reproduction of behaviour from previous governments. In summary, it is argued in the paper that, while class remains the defining fissure of current Venezuelan politics, race is its rarely examined subtext.

\section{Class-based polarisation in Venezuela}

Although historically class was elided from discourse in Venezuelan politics, support for President Hugo Chávez is largely polarised along class lines, a fact that has been recognised by a number of political analysts. Using poll data from 1995 and 1998, Canache finds that it was the poor who mostly supported Chávez's failed coup in 1992 against President Carlos Andrés Peréz, and in a survey in 1995 his support was strongest among the lower economic sectors. ${ }^{4}$

In the 1998 presidential elections Roberts points to strong support among the poor for Chávez, whereas his chief rival Henrique Salas Römer's appeal was among the middle and upper sectors. ${ }^{5}$ Canache provides further evidence of this support, showing that, in a pre-election survey conducted just before the 1998 presidential elections, $55 \%$ of the urban poor declared their intention to vote for Chávez, whereas only $45 \%$ of the non-poor expected to back him. ${ }^{6}$

Similarly in the 2000 presidential elections one poll found that $50.5 \%$ of socioeconomic sector E intended to vote for Chávez as opposed to $24 \%$ for Arias Cardenas, his principal opponent and co-conspirator in the 1992 coup, while $66.7 \%$ of socioeconomic groups $\mathrm{A}$ and $\mathrm{B}$ intended to vote for the latter. ${ }^{7}$ A poll published by Venezuelan polling firm Datanalisis in 2001 found a similar tendency. ${ }^{8}$ 
Canache, however, predicted that the urban poor of Venezuela would become disillusioned with Chávez and cited poll data to prove this at the conclusion of her study. Nonetheless, poll data posterior to publication of that study reinforce rather than negate the tendency of support for Chávez among the poor. In a poll by Greenberg, Quinlan and Rosner in 2004, shortly before the revocatory referendum held on President Chávez's mandate, $80 \%$ of those polled in the $\mathrm{A} / \mathrm{B} / \mathrm{C}+$ social category intended to vote for his removal from office $(\mathrm{Si})$, while close to $60 \%$ of those in the E social category would vote against $(\mathrm{No})$. Canache based her prediction on Chávez's failure to deliver promises made to the poor yet, when asked for reasons in this poll why they chose to vote in favour of Chávez, $62 \%$ said they believed that Chávez helped the poor and almost $60 \%$ evaluated the government's misiones or social programmes (see below) favourably, reinforcing the link between Chávez and the lower class in popular opinion. ${ }^{9}$

More recently still, similar data was found in an Evans/Mc Donough Company/Consultores 30.11 poll published on 29 November 2006, just over a week before the 6 December presidential elections of that year. ${ }^{10}$ In this poll $76 \%$ of social strata $\mathrm{A} / \mathrm{B}$ and $47 \%$ of stratum $\mathrm{C}$ said they would vote for Manuel Rosales, Governor of Zulia province and Chávez's main rival, while $64 \%$ of stratum D and $68 \%$ of stratum E intended to vote for Chávez. These two strata made up the majority of respondents, representing jointly $62 \%$ of the total. In the event Chávez won that election by $62 \%$, while the turnout was $75 \%$ of registered voters. These findings are shown in Table 1. Chávez's support among the poor has therefore remained relatively consistent over the eight years since he was first elected in 1998.

TABLE 1. Class/race polarisation in Venezuela-poll data 2000-06

\begin{tabular}{|c|c|c|c|c|c|}
\hline Year/social class & A & $\mathrm{C}$ & $\mathrm{D}$ & $\mathrm{E}$ & $\begin{array}{c}\% \text { in } \\
\text { election }\end{array}$ \\
\hline $\begin{array}{c}\% \text { social class in } \\
\text { overall pop }\end{array}$ & 5 & 35 & 39 & 21 & 100 \\
\hline 2000 & $66.7 \%$ (Opp) & $\mathrm{N} / \mathrm{A}$ & $\mathrm{N} / \mathrm{A}$ & $50.5 \%(\mathrm{Ch})$ & $\begin{array}{c}59.76(\mathrm{Ch}) \\
37.52(\mathrm{Opp})\end{array}$ \\
\hline 2004 & $\begin{array}{l}80 \%(S i)^{*} \\
15 \%(N o)^{*}\end{array}$ & $\begin{array}{l}61 \%(S i) \\
34 \%(N o)\end{array}$ & $\begin{array}{l}51 \%(\mathrm{Si}) \\
43 \%(\mathrm{No})\end{array}$ & $\begin{array}{l}38 \%(\mathrm{Si}) \\
59 \%(\mathrm{No})\end{array}$ & $\begin{array}{l}40.63(\mathrm{Si}) \\
59.9(\mathrm{No})\end{array}$ \\
\hline 2006 & $\begin{array}{l}76 \%(\mathrm{Opp}) \\
17 \%(\mathrm{Ch})\end{array}$ & $\begin{array}{l}47 \% \text { (Opp) } \\
48 \%(\mathrm{Ch})\end{array}$ & $\begin{array}{c}32 \%(\mathrm{Opp}) \\
64 \%(\mathrm{Ch})\end{array}$ & $\begin{array}{c}26 \%(\mathrm{Opp}) \\
68 \%(\mathrm{Ch})\end{array}$ & $\begin{array}{c}38.39 \text { (Opp) } \\
62(\mathrm{Ch})\end{array}$ \\
\hline
\end{tabular}

Notes: *Sí refers to the option in favour of removing Chávez; No to the option against. Opp = Main Opposition Candidates: Francisco Arias Cardenas (2000), Manuel Rosales (2006). $\mathrm{Ch}=$ Hugo Chávez Frías, President of Venezuela.

Sources: Author's own elaboration, based on Carlos Subero, 'Clases sociales tienen distinto candidato', El Universal (Seccíon Nacional y Política), 6 April 2000, at http://www.eluniversal.com/2000/04/06/06102AA. shtml, accessed 20 June 2003; Greenberg, Quinlan and Rosner, 'Venezuela, Resultados Estudio de Opinión Pública Nacional: Junio 23, 2004', at www.rnv.gov.ve/noticias/uploads/encuesta-greenberg-junio-2004.ppt, accessed 15 January 2008; Evans/McDonough Co/Consultores 30.11, 'Clima Política Votantes Venezolanos: Presentación de resultados', 2007, at http://www.rethinkvenezuela.com/downloads/PRESENTACION_ ENCUESTA_NACIONAL_NOVIEMBRE_2007.pdf, accessed 15 January 2008; and Consejo Nacional Electoral, Resultados Electorales [online], at http://www.cne.gov.ve, accessed 13 November 2007. 
Chávez's rise therefore signifies 'a repoliticisation of social inequality in Venezuela' with mostly the popular sectors identifying with Chávez and the middle and upper sectors with opponents of the president. ${ }^{11}$ The main argument in this paper, however, is that there is a racial subtext to this support. On the one hand, the poor's support for Chávez is based on the fact that he is like them: from a poor background and pardo (of mixed Indigenous, African and European descent). The figures presented in Tables 2 and 3 below would seem to support this suggestion. Conversely, the rejection of Chávez by parts of the middle and most of the upper classes in Venezuela is precisely a rejection of these very qualities: being poor and dark-skinned. This rejection is furthermore based on a deeply rooted historical rejection of the Black as being culturally and socially inferior to the White. Despite, as Wright points out, the 'seamier sides of racism' being eradicated during the pre-Chávez period (1958-93), ${ }^{12}$ the so-called puntofijo era, ${ }^{13}$ this association of the Black with backwardness remains strong in Venezuela, especially in terms of media depictions of the poor. Dark skin, as we shall see, is still associated with poverty and, the darker the skin, the more likely that that person will belong to the poorer sections of society. Thus race and class remain associated in Venezuela, despite advancements in eradicating some elements of racism.

In order to prove this, let us first examine the substantive point of this article, that class divisions in Venezuelan politics have an element of ethnic and race division within them, before going on to examine more closely the association of race and class in Chávez's discourse and policy, as well as looking at classist and racist elements in opposition anti-Chávez discourse.

\section{Race/class interaction}

Despite views to the contrary, racism still exists and operates in Venezuela and this racism has deep roots in the country's colonial past. Furthermore, in Venezuela as in much of the rest of Latin America, concepts of race and class fuse, whereby generally speaking it is believed that the darker a person's skin, the poorer that person will be.

Before looking at the concepts of race and class in the context of Venezuelan history, we first of all need to look at the relationship between these two concepts in sociological theory to provide a theoretical background to this contextual discussion.

Miles and Brown see the concept of 'race' and 'races' as 'socially imagined rather than biological realities'. In a nutshell they see the phenomenon of race and racism as diverse but one that always centres on an ideology based on what they call a Self/Other dialectic. This ideology is twofold, they argue. Following Taguieff the act of racialisation of a given population, attributes that Other with negative attributes ('autoracialisation'), while simultaneously and automatically giving the Self positive attributes. Hence, for example, European colonial discourse on Africans portrayed them as 'less civilised, a barbarian, by virtue of supposedly looking more like a beast and behaving in ways that approximated to the behaviour of a beast'. ${ }^{14}$ Conversely, the Self, 
the European was seen as being the epitome of civilisation and human development. Such a conceptualisation, Miles and Brown argue, seeks 'to claim the authority of a natural (and therefore unalterable) difference [and] ... is the prelude to exclusionary practices'. ${ }^{15}$

So what is the relationship, then, between the concept of race and that of class? The two are interlinked they argue because both perpetuate inequality. 'Racism is a denial of humanity (substituting, as it does, 'races' for 'the human race') and a means of legitimating inequality (particularly inequality explicit in class structures). ${ }^{, 16}$ How they interact, however, will depend on the class position of those practising racism, because 'Erlebnis (lived experienced of the world) and its consequent problems vary with class position'. ${ }^{17}$ Indeed, the forms and expressions of racism have had "varying interaction with economic and political relations in capitalist and non-capitalist social formations', ${ }^{18}$ hence any discussion of racism must therefore be 'historically specific [as it is] knowable only as a result of historical analysis rather than abstract thinking'. ${ }^{19}$ Consequently discussion on racism in Venezuela and its relationship to class must be looked at in an historical context to be properly understood, which is our task in the next few sections.

\section{Colonial and early republican contexts}

During the colonial era Venezuela had small indigenous populations relative to the richer colonies of Peru and Mexico, so consequently it had to import labour through slavery from Africa, at considerable cost, both human and economic. In the period from the Conquest up until 1797, when the African slave trade ended, 100000 Africans entered Venezuela. ${ }^{20}$ These slaves were harshly treated both physically and socially and the black and the indigenous would remain stigmatised within Venezuelan society from thence on.

Venezuela nonetheless became one of the more racially mixed colonies of Spanish America, as a process of miscegenation began there from the earliest times of the colony. By the end of the colonial era $60 \%$ of Venezuelans had African origins and, of the $25 \%$ classified as white, probably some $90 \%$ had some African ancestry. ${ }^{21}$ This would have repercussions for the country's view of itself in later years, and of its inhabitants of themselves, as we shall see.

Gott sees this era in Latin America in terms of a 'white settler' society paradigm. Seeking to 'eliminate the indigenous population', either physically or through policies of assimilation, ${ }^{22}$ white settlers in Latin America set out to achieve this by 'simultaneously oppressing two different groups within their territory: they seized the land of the indigenous peoples, and they appropriated the labour of the black slaves that they had imported'. ${ }^{23}$

Republican Venezuela retained or assumed the characteristics of colonialism, resulting in the Latin American white settler elite having a Eurocentric approach to society and nation building, and a deep mistrust of native and African conceptions of community and society. ${ }^{24}$ In consequence the white settler elites of Latin America had more in common with the elites of Europe and North America than with their fellow Latin Americans, leading to an 
'ingrained racist fear and hatred of the white settlers, alarmed by the continuing presence of the expropriated underclass'. ${ }^{25}$ Struggles between rich and poor in Latin America were therefore not only class-based but also racebased, a fact, Gott notes, that 'even politicians and historians of the Left' have ignored, preferring to 'discuss class rather than race'. ${ }^{26}$ Venezuela was no exception within this pattern, although it has had distinct overtones because of its individual historical trajectory, as we shall see.

\section{Miscegenation in modern Venezuela}

This rejection of the black and the indigenous continued into the 20th century through the ideology of mestizaje (miscegenation), also known as the myth of democracy or racial equality, [which] served to mask racial discrimination and the socioeconomic situation of the Afro-Venezuelan and indigenous communities'. ${ }^{27}$ In this ideology the white European was identified as 'the civilizing agent, making Africans and the indigenous and their descendants largely invisible'. ${ }^{28}$ This ideology also 'denied the existence of social classes', and instead looked to a cultural homogenisation, spread primarily through the educational system. ${ }^{29}$ This policy of mestizaje and the denial of racism within Venezuela continued into the liberal democratic puntofijo regime, installed definitively in 1958.

The puntofijo regime was designed to avoid conflict and antagonism, to encourage conciliation and to negate the polarisation of Venezuelan society along class and, following the logic of our argument, racial lines. Access to the vote, to education and to health services, and an expanding middle class, temporarily ameliorated the worst excesses of class/race divisions in Venezuela, forging even further the myth of a classless, non-racist, united Venezuela. Yet, as time went by, the economic model began to be exhausted under the weight of a slump in oil prices and increased external borrowing.

From Black Friday in February 1983, when the government of Luis Herrera Campins dramatically devalued the bolivar in the face of a slump in oil prices and massive capital flight, the regime began to crumble. On the economic level, for example, Venezuelans saw their standard of living plummet. Between 1990 and 1997, according to the UN, per capita income fell from US\$5192 to \$2858, and Venezuela's human development index from 0.8210 to 0.7046 . $^{30}$

With this economic crisis the vision of a united, non-racial and classless Venezuela lost its mythical power. Racist discourse began to re-emerge among the upper and middle classes. The link between class and race became more explicit as Afro-Venezuelan and indigenous people became the scapegoats for Venezuela's economic failure. Ishibashi shows how stereotypes of the fecklessness and indolence of Afro-Venezuelans were perpetuated through the Venezuelan media. As Ishibashi puts it: "The "white" is normally the symbol of the beautiful, the rich, the pure and the sophisticated, while the 'black' is the symbol of the ugly, the poor, the impure and the nonsophisticated'. ${ }^{31}$ Black people in the Venezuelan media, in advertisements, TV soaps, cinema and in beauty pageants, are practically 'invisible'. When they 
are seen, they are often associated with partying on the beach, reinforcing the idea of the black as being 'feckless', or in a position of providing a service of physical labour.

Class plays a role in the depiction of blacks in the Venezuelan media, with products directed at the upper classes usually being advertised by white models, while those directed at the popular classes usually use darker skinned models. As one media photographer admits: 'the darker the [skin] colour, the more [models] are associated with the lowest social classes'. ${ }^{32}$ Indeed, not only is 'colour associated with [social] classes' but Afro-Venezuelans are also, as we have seen, associated with the 'ugly'. ${ }^{33}$ This reinforces the association in the popular mind of the 'West' or the 'white' being associated with the 'superior and civilised' while the rest are 'inferior and savage'.

It is of no surprise then that in surveys done on ethnicity within Venezuela, those who identify themselves as 'Afro-Venezuelan' are in a small minority, of much less significance than those who identify themselves as white. For example, in the 2007 World Values Survey in Venezuela, $4.2 \%$ of respondents identified themselves as Black-Other/Black, whereas $35.8 \%$ identified themselves as White/Caucasian White. Nevertheless, the survey also provides a number of intermediate options, such as 'Coloured-Dark' $(16.6 \%)$ and 'Coloured-Light' (42.7\%). Indigenous groups, on the other hand, represent only $0.5 \%$ of the population but, despite their small numbers, have important symbolic value. ${ }^{34}$

Apart from the highly subjective nature of such categories (what is the actual physical difference between Black and 'Coloured-Dark'?), not to mention the high probability that those who identify themselves as 'Caucasian-White' have some element of Black or Indian blood (as noted by Ewell ${ }^{35}$ ), the important point to note is that the majority of Venezuelans, roughly $64 \%$, identify themselves as non-white. It is important also to point out that, in a social context where the Black is highly undervalued, if not despised, the probability of Venezuelans not identifying themselves with that ethnic category is doubtless increased.

While at the time of writing it appears that no figures exist providing a breakdown of the racial make-up of each social class in Venezuela, it is instructive to compare social class breakdown with that of racial categories. As we can see in Tables 2 and 3, if we compare the total of social sectors $\mathrm{A}+\mathrm{B}+\mathrm{C}$, at $40 \%$, with the total of those who identified themselves as White, at $35.8 \%$, we find a strong similarity in the percentages found pertaining to both these categories. Similarly, if we compare the total of sectors D+E, the poorest social sectors, at $60 \%$, with the total of those who identified as nonwhite (ie black, coloured dark, coloured light and indigenous) at $64.2 \%$, again we find a high level of correlation between both sets of figures. This suggests, although by no means definitively, that there is a strong level of probability that those who identify as white are found in the higher social sectors, while those who identify as black, mixed raced or indigenous are found in the D or E social categories. If we then go on to look at the figures in Table 1 above, showing voting patterns in favour of President Chávez, we find similar correlations between percentages in all three sets of figures. In 
BARRY CANNON

TABLE 2. Venezuelan social class sectors, population breakdown

\begin{tabular}{|c|c|c|c|c|c|}
\hline Social class & $\mathrm{A}+\mathrm{B}$ & $\mathrm{C}$ & $\mathrm{D}$ & $\mathrm{E}$ & Total \\
\hline$\%$ social class in overall pop & 5 & 35 & 39 & 21 & $100 \%$ \\
\hline Total $\mathrm{A}+\mathrm{B}+\mathrm{C}$ and $\mathrm{D}+\mathrm{E}(\%)$ & \multicolumn{2}{|c|}{40} & \multicolumn{2}{|c|}{60} & 100 \\
\hline
\end{tabular}

Note: $(\mathrm{A}, \mathrm{B}, \mathrm{C}+)$. Social strata vary from poll to poll but generally those in $\mathrm{A}, \mathrm{B}$ and upper $\mathrm{C}$ are regarded as in high-income brackets; $\mathrm{C}$ - in the middle income bracket and D and $\mathrm{E}$ in the low income bracket, the poorest income stratum.

Source: Author's own elaboration, based on Greenberg, Quinlan and Rosner, 'Venezuela, Resultados Estudio de Opinión Pública Nacional: Junio 23, 2004', p 24, at www.rnv.gov.ve/noticias/uploads/encuestagreenberg-junio-2004.ppt, accessed 15 January 2008.

TABLE 3. Racial category breakdown for Venezuela

\begin{tabular}{lcccccc}
\hline Racial category & White & Coloured (light) & Coloured (dark) & Black & Indigenous & Total \\
\hline \% race in overall pop & 35.8 & 42.7 & 16.6 & 4.2 & 0.5 & 100 \\
Totals (white/non-white, \%) & 35.8 & & 64.2 & & & 100 \\
\hline
\end{tabular}

Source: Author's own elaboration, based on World Values Survey, 'Online Data Analysis, Venezuela1996, 2000: Sociodemographics - Ethnic Description', at http://www.jdsurvey.net/bdasepjds/wvsevs/home. jsp?OWNER=WVS, accessed 15 January 2008.

Categories were self-selected by respondents from presented options.

other words, there is a high probability, judging by these figures, that a poorer Venezuelan, with darker skin, will vote for Chávez).

These figures suggest furthermore that, as Herrera Salas emphasises, racism is not just a social phenomenon in Venezuela but has a political economy rationale also. ${ }^{36}$ This is reinforced by the dependent situation of Venezuela's economy. Structured employment, wealth, taxation and the distribution of social goods in Venezuela are subject to influence by the structural factors of race/class and economic relations with the core capitalist countries. Economic dependence preserves underdevelopment, perpetuating the existing class/race bifurcation and the inequalities stemming from these basic societal cleavages, which in turn itself further perpetuates economic dependence.

Both these factors have resulted in a stratified society based on race, with non-white majorities having limited access to the scant formal employment opportunities available. The white or 'near-white' elite, on the other hand, acts as the mediator between local markets and capitalist centres, with local capitalists playing a reduced role in the local market, providing basic consumer goods (such as beer, wine, flour etc) to it but few high-value manufactured products.

These economic and cultural tendencies led the country to a deepening political polarisation which, as we shall see in the next section, became most apparent during the second presidency of Carlos Andrés Peréz (1989-93) as he attempted to introduce a neoliberal restructuring programme into Venezuela. 


\section{The rise of neoliberalism and the death of a united Venezuela}

The introduction of neoliberal policies by Peréz sparked off the greatest public disorders seen in modern Venezuelan history, which came to be known as the Caracazo (27-28 February 1989). Peréz brought in a number of IMFsponsored economic measures, including the raising of fuel costs with a concomitant rise in public transport charges. This provoked residents of Caracas's overcrowded shantytowns, and those in many other Venezuelan cities, to come down from the cerros (hills) and proceed to loot shops and warehouses, initially for food, but, as the disturbances developed, for all sorts of consumer goods. Government reaction was initially tame but eventually President Pérez called a state of emergency and left it to the army and police to quell the disturbances. The result was the use of 'massive violence' and an official death toll of 277 , an unofficial one running into the thousands. ${ }^{37}$

Establishment presentations of the Caracazo unearthed once again the barely latent classism and racism buried under the official myth of a classless and non-racial Venezuela. To those in power the Caracazo represented the eruption of barbarism, of primitivism pitted against civilisation. The pueblo (people) were a source of barbarism, the government and the elite a force for reason and civilisation; 'the nation was split in two'. ${ }^{38}$ After the Caracazo Venezuela would not be the same again, as protest became the norm, increasing both in incidence, violence and variety and extending to almost all sectors of society. ${ }^{39}$ It symbolised the eruption of the class factor once again into the national political arena and, following the logic of our argument, also the question of race.

Despite President Peréz admitting the class nature of the disturbances and accepting that it was the economic measures which sparked them off, ${ }^{40}$ he persisted in their implementation, leading initially to some macroeconomic success. By 1992, however, unemployment, informalisation of employment and poverty had all increased. ${ }^{41}$ Meanwhile, as the Venezuelan population in general and the popular classes in particular paid the price of economic reform, the governmental and business elites were seen to be enriching themselves even further through financial speculation and/or corruption. Dissatisfaction grew and in 1992 Peréz's government was rocked by two unsuccessful coups, the first led by Lt Col Hugo Chávez on 4 February. While the coups failed, by 1993 Peréz was impeached and under house arrest for corruption, finally going into exile, where he still remains.

This cleared the way for the emergence of Chávez as a political force in the country and, as we have seen in the first part of this paper, his support came mostly from the poor of Venezuela. Yet, as we have sought to prove, the vast majority of these poor are the darker skinned, black or pardo citizens of Venezuela. The next section will seek to answer the following question therefore: why do the poorer, darker skinned majorities of Venezuela vote for Chávez? Two reasons are offered for this: first, Chávez has exalted the nobility of the ordinary Venezuelan in his discourse, and emphasised that the ordinary Venezuelan is poor and of mixed-race extraction, like himself. Second, the Chávez government has directed policy towards improving the social and 
economic situation of the poor, pardo Venezuelan. This contrasts greatly with opposition discourse and policy which has subtle, and sometimes not so subtle, racist and classist elements causing distrust among most poor Venezuelans.

\section{Chávez's discourse on class and race}

The 'people': race and class in chavismo

The movement launched by Chávez adopted as its ideology a system of thinking specifically Venezuelan and Latin American, bolivarianismo, rather than one based on imported ideologies. Bolivarianismo is based on the thinking and teachings of three major figures from Venezuelan history: Ezequiel Zamora, popular military leader in the Federal Wars; Símon Rodríguez, educator, friend and mentor to the final member of the trinity, the Liberator, Símon Bolivar. Each figure provides a specific element to the new ideology: Zamora the element of rebellion, popular protest and protagonism, summed up in the slogan attributed to him: 'Land and free men! Popular elections! Horror to the oligarchy!'; Rodríguez the requirement for autochthonous ideological originality when he warned that 'either we invent or we commit errors ... America should not servilely imitate, but be original'; and Bolivar, the Liberator, the symbol of equilibrium between the dualism of rebellion and ideology, force and consent. ${ }^{42}$

Central and crucial to this ideology is the concept of el pueblo, the people. It is of interest here to have a diversion into the theoretical meaning of the concept of the people, as developed by Ernesto Laclau in his theories on populism. For Laclau, the people are not so much a coalition of identities, as portrayed by many analysts of populism, but rather invest their diverse identities into one privileged identity. He illustrates this with the distinction between the people as populus, the body of all citizens, and as plebs, the underprivileged. The 'people' of populism comes about when the plebs represent the populus - that is, a partiality which wants to function as the totality of the community'. ${ }^{43}$

Central to this process of construction of the 'people' is the role of the leader. Populist leaders are often drawn by analysts as strong, charismatic and paternalistic macho men, with an autocratic, authoritarian bent. They are seen as 'outsiders' and are portrayed as manipulative of the 'people', autocratic, power hungry and ambitious. Laclau, however, resists attributing the prominence of the leader in populist movements to these characteristics. Populism for him is a chain of demands whose unity is expressed through one element of those demands (in this case the plebs). In other words, the totality is expressed through a singularity and the extreme form of a singularity is an individuality. The group, the totality of the populus, becomes symbolically unified around an individuality, in this case the leader. The 'leader' therefore 'is inherent in the formation of a people'. ${ }^{44}$ Panizza clarifies this position further. For him, the leader is 'an enigma that promises meaning: the promise of a fully reconciled people'. ${ }^{45}$ The leader therefore comes to signify the people themselves, or rather what the people strive for. 
This process can be seen in the relationship between Chávez and the 'people' in Venezuela. Chávez reifies the people in his discourse. For him, "popular protagonism [is] the fuel of history' and only when this protagonism exists is a people truly el pueblo. ${ }^{46}$ The Venezuelan people specifically are a true people, a people who have shown, and are capable once again of greatness:

we are one of the liberating peoples of the world, we are a people of creators, of poets, of fighters, of warriors, of workers, there's history to prove it, let's honour it, let's honour the spirit of our aborigines, of our liberators, of our women, of our youth... all of that we have in our veins and in the clay from which we were made, let us show it, it is the moment to show it. ${ }^{47}$

Leadership is vital to achieve the necessary protagonism lying dormant in the people, so that the people become a people actively struggling. Chávez rejects the notion of the caudillo, the leader/masses model put forward by many of his critics. Leadership must be provided in order to galvanise the collective into action, but the leader is but a conduit. The people are an 'unleashed force, equal to the rivers' being channelled by leaders such as Chávez because either 'we provide a course for that force, or that force will pass over us' ${ }^{48}$ Chávez is 'not a cause, but a consequence', 49 'an instrument of the collective'. 50

Race and class are central sources of identification with the concept of el pueblo for Chávez. Chávez repeatedly emphasises his background as a pardo and as a common man. Kozloff quotes Chávez as saying: 'My Indian roots are from my father's side... He [my father] is mixed Indian and black, which makes me very proud.' He also boasted, according to Kozloff, that his grandmother was a Pumé Indian. Kozloff goes on to report that, apart from being pardo, 'Chávez was [also] born in extremely humbling conditions in the llano [Orinoco plains area of Central Venezuela]: "I was a farm kid from the plains of South Venezuela," he remarked to Ted Koppel on ABC's Nightline. "I grew up in a palm tree house with an earthen floor," he added'. 51 Chávez frequently refers to cultural symbols associated with grassroots Venezuelan communities: the arepa, a corn bread that is part of the staple diet for ordinary Venezuelans, baseball, the national sport, and he occasionally breaks out into a typical Venezuelan song in the middle of a speech, which is often laden with colloquialisms.

On another occasion Chávez pointed out the links between racism in the USA and the underlying racism in discourse against Chávez himself:

Racism is very characteristic of imperialism. Racism is very characteristic of capitalism... Hate against me has a lot to do with racism. Because of my big mouth, because of my curly hair. And I'm so proud to have this mouth and this hair, because it is African.

In the end, Chávez insists it is socialism, 'a new ethic', which is needed 'to beat those ominous phenomen[a] such as racism'. ${ }^{2}$

Through discourse celebrating the common man and his ethnic background, Chávez is underlining his similarities with the majority of Venezuelans. As we have seen, most Venezuelans are black or mixed race, 
with some indigenous $(64 \%)$ and most are in the lower socioeconomic brackets $(62 \%$ in strata $\mathrm{D}$ and $\mathrm{E})$. It is probably no accident therefore that in the last presidential elections in 2006, similar percentages of the population voted for Chávez $(62 \%$ out of a turnout of $75 \%)$.

\section{Opposition discourse on class and race}

The Chávez discourse celebrating race and class contrasts greatly with that emanating from opposition elements. Some of this discourse presents deeply subtle forms of racism and classism, whereas some of it is much more overt. In it the image is projected of a pueblo being easily manipulated and incapable of thinking rationally. Pedro Carmona Estanga, for example, leader of peak business organisation, Fedecamaras and erstwhile president for 48 hours during the coup against Chávez in April 2002, wrote in an article published shortly before the 1998 presidential elections that 'people don't understand the Constituyente but simply emotionally follow the candidate that is promoting it'. Francia gives further examples of this, where the vote for Chávez is considered an 'emotional' vote, while votes against him are considered 'rational'. ${ }^{53}$ Similarly Julio Borges, leader of US-funded political party Primero Justicia (Justice First), qualifies those who vote for Chávez as 'inhabitants' not 'citizens', implying that they acted without thinking. ${ }^{54} \mathrm{On}$ field work to Venezuela in 2002 I found that some people rejected Chávez because, according to them, Venezuela needed 'gente preparada', educated, trained people, this despite the fact that Chávez has a BSc in military science and studied for a Masters in Political Science.

Less subtle forms of racism and classism are also found in opposition discourse on Chávez supporters. In March 2004, during a high-level international summit in Caracas, opposition television station Globovisión parodied President Robert Mugabe of Zimbabwe as a monkey, prompting six African countries to object. ${ }^{55}$ Herrera Salas points to a visceral racism and classism directed towards the president and his supporters by opposition members and media, where the president is routinely referred to as 'Indian, monkey and thick-lipped' or simply as a 'monkey'. ${ }^{56}$ Supporters of Chávez are regularly referred to as 'hordes' and the pro-government Bolivarian Circles as 'terror circles'. Duno examines how media portrayals of Chávez supporters suggest this image of the mob as one 'swayed by its leader, or moved by base emotions, failing to exercise its will in a rational fashion'. Worse, the image is of 'those people [who] go on marches because they are paid to or because it gives them a chance to get drunk'. ${ }^{57}$ These portrayals of Chávez supporters have underlying them a profound racial and classist bias.

Duno shows us by recounting several examples of media racism against Chávez supporters that it is indeed the construction of a "national political imaginary. . .articulated on the basis of racist thought' ${ }^{58}$ In the end the main thrust of these disqualifying media presentations of Chávez supporters, Duno asserts, are 'a strategy to remove political legitimacy from marginalised social subjects ${ }^{, 59}$ who are in effect political actors who have challenged power. ${ }^{60}$ 
Furthermore, as Wilpert asserts, this is a strategy on the part of the old established elite, removed from power by Chávez, to attempt to regain that power. The old elite uses 'its control of the country's mass media to turn the middle class against Chávez, creating a campaign that took advantage of the latent racism and classism in Venezuelan culture'. ${ }^{61}$

Some opposition analysts, while recognising this racism and classism within the opposition ranks, blame Chávez for this situation. For Patricia Marquez of the elite Instituto de Estudios Superiores de Administración (IESA), for example, it is Chávez who has 'stirred up the beehive of social harmony'. ${ }^{62}$ Yet, Herrera Salas counters, it 'is evident...that [Chávez's] political discourse and the symbolic and cultural practices of the Bolivarian Revolution have emphasised so-called national values, significantly reducing the occurrence of ethnic shame and endoracism in the popular sectors' ${ }^{63}$ This chavista discourse has been translated into numerous policy initiatives which have further recognised the existence of the class and race fractures in Venezuelan society, as we shall see in the next section.

\section{Bolivarian race and class policy}

In general indigenous and Afro-Venezuelans, as well as the majority pardo population, can take advantage of the various missions set up by the Chávez government to ensure greater access for the popular classes in a variety of social areas. Indigenous groups also have their own, specific misiones. Mujica and Rincón group these into the following areas: 1) education; 2) health; 3) food and salaries; 4) employment; 5) land; 6) indigenous and 7) identity. ${ }^{64}$ Under 'education' there is a number of missions: Missions Robinson I covering basic literacy and II covering the completion of primary education. Mission Ribas covers secondary education and Sucre third level, both of these providing monthly scholarships of $\$ 100$ for each student.

Under 'health' there is the most important Mission 'Into the Neighbourhood' (Barrio Adentro) which establishes health clinics in shanty towns covered by Cuban medical personnel. There are also the Miracle Mission (Mision Milagro) providing eye operations for children in Cuban hospitals and Sports Mission (Mision Deporte) promoting sport in marginalised areas. Under food and salaries there is Mercal Mission, which provides low-cost food stuffs through a state-run store network, as well as the Maximum Protection Programme providing half-price basic food stuffs and comedores populares or Soup Kitchens providing low-cost meals.

In employment, Mission Turn Heads (Mision Vuelvan Caras) builds on the work of the educational missions by helping their graduates find work, while Piar Mission helps mining communities. On land, Mission Zamora, associated with the Land Law, works on land distribution to poor families as well as providing credit, technical assistance, training and infrastructure. Mission Guaicapuro promotes the integral development of indigenous communities, ensuring that their constitutional rights are delivered. Finally, the Housing Mission seeks to guarantee the right to housing and the Identity Mission to ensure that everyone obtains legal identity documents. 
In general it is estimated that, of the $\$ 40.5$ billion dollar 2006 budget, $41 \%$ was dedicated to social programmes and that social spending has increased threefold since Chávez came to office in $1998 .{ }^{65}$ Much of that social spending went on the various misiones explained above.

The Chávez government has also attempted to tackle disadvantage based on race, for the indigenous at least. Indigenous people are guaranteed through Article 121 of the Bolivarian Constitution the right to maintain their cultural identity, the state's promotion of that right, and the right to education in a culturally appropriate manner. There are reserved seats in the National Assembly for indigenous people and some indigenous have occupied high-level posts, such as Noelí Pocaterra, who became vicepresident of the National Assembly. The Organic Law for Indigenous Peoples and Communities (LOPCI in its Spanish acronym), passed in 2006, set up the National Institute of Indigenous Peoples (INPI) run by the indigenous and charged with establishing the procedures for the demarcation of Indigenous Lands and Habitats. Other laws passed include the creation of a Vice Ministry for Indigenous Affairs, new health care initiatives and the extension of the Mision Guaicapuro in education.

There is, however, no corresponding recognition of Afro-Venezuelans in the Constitution and, as a result, no pro-Afro-Venezuelan legislation, despite representations from Afro-Venezuelan groups. In a package of proposed amendments to the Constitution formulated in August 2007, however, such recognition was finally proposed. This package was rejected by the Venezuelan people in a referendum in December of that year, largely because of controversial proposals to extend presidential powers.

Nonetheless, we can see from this brief summary that Chávez himself has prioritised class and race issues in discourse and many policy initiatives have tackled classism directly, with race issues being subsumed within these more general programmes, except in the case of the indigenous. The question remains, however, to what extent this represents a genuine change in the structure of Venezuelan society. We turn to this question in the next section.

\section{Class and race in Venezuela: a break with the past or the song remains the same?}

Despite the advances outlined above there are several problems in their design and delivery, as well as resulting from the historical context, which have limited the impact of change for the popular classes, in their majority pardo, Afro-Venezuelan and indigenous peoples of Venezuela.

Of all the initiatives aimed at eliminating disadvantage along class lines, the Missions have been most successful. The combined effect of the Missions and other social programmes has resulted in a drop in poverty from $44 \%$ of households in 1998 to $31 \%$ in 2006. This, as Weisbrot et al point out, only covers cash income ${ }^{66}$ - the combined effects of the abovementioned missions, most of which are not cash-based, may have further reduced poverty in Venezuela. For example, the Venezuelan government has provided free health care to an estimated $54 \%$ of the population and subsidised food for 
$40 \%{ }^{67}$ Furthermore, the management of these missions provides much popular participation, through a variety of novel mechanisms such as local health committees (comités de salud) or local communal councils (consejos comunales) to develop and manage local affairs at neighbourhood level.

In its annual evaluation of human rights for 2004-5 the independent Venezuelan human rights organisation, PROVEA, hails the advances towards social justice and equality during Chávez's years in power. These improvements have been particularly felt, they note, among the poorest sections of society, with an important increase in income for socioeconomic stratum E, the group, as we have seen, which provides the bedrock of popular support for the Chávez government. PROVEA sees these tendencies as a democratising force, increasing equality and social justice. ${ }^{68}$

In the following year's report (2005-06) it recommends, however, improvements in five key areas in order to ensure lasting structural changes in favour of all, but particularly the traditionally excluded. ${ }^{69}$ These are:

1. Integrating Missions into the existing institutionality and putting them under more rigorous cost and evaluation controls.

2. Creating a real division of powers between institutions, reducing the protagonism of the presidency, and reversing the tendency towards the militarisation of Venezuelan society.

3. Fostering an appropriate climate to handle conflict and reach consensus through the creation of more space for dialogue.

4. Providing a National Plan for Human Rights with ample popular participation.

5. Ensuring the participation of the population in public affairs, guaranteeing citizenship and the autonomy of social organisations.

'Who governs in the next six years' PROVEA concludes, 'have the challenge to construct a democracy with social justice, solid and efficient institutions, less poor people, with citizens more conscious of their rights, and with a significant decline in human rights abuses and impunity, as well as creating adequate conditions for the exercising and enjoyment of all human rights without discrimination' ${ }^{70}$

While the Chávez government has advanced notably towards a number of these goals since coming to power in 1999, and while discursively in particular it has clearly voiced its wish to aim towards many of them, in practice it still has quite some way to go. The most recent 2006-07 PROVEA survey notes that Venezuela is in a state of transition between the old puntofijo republic and a new form of state aiming towards a 'socialism of the XXI century'. Within Venezuelan society there is a battle, within and without the government, between those whose actions are characterised by authoritarianism and those aiming towards a full participative democracy. ${ }^{71}$ It remains to be seen if, in the remaining five years of Chávez's second full mandate, he will aim towards the latter with the necessary vigour to ensure popular participation for all, especially those traditionally excluded on the 
basis of class and race, and thus truly reverse the historical patterns which helped create the space for him to emerge as a leader in the first place.

\section{Conclusion}

To conclude, our survey shows that the bulk of Chávez's support emerges from the poorer, darker skinned sectors of Venezuelan society. This has two implications: first, that there is a polarisation around class in Venezuela, with a powerful racial subtext which points to the emergence of a class-based political system for the present at least. Second, in terms of the study of Venezuelan politics and Chávez's support in particular, that there is a complex interrelation between class and race in this area. However, this has only been a tentative exploration to highlight this fact and, if anything, the issue needs more detailed research to draw out its full implications.

\section{Notes}

This paper was first presented at the 'Current Political Processes in Latin America' Panel held at the Society of Latin American Studies (SLAS) Annual Conference, Newcastle University, 13-15 April 2007, convened by Dr Gustavo Emmerich (Universidad Autónoma Metropolitana, México City). Thanks to Dr Emmerich and all those who commented on the paper at the SLAS panel. Thanks also to the anonymous reviewer who commented on my paper for TWQ, and to my colleague David Doyle at Dublin City University. Finally this paper would not have been possible without fellowship funding provided by Irish Aid, the Irish government's development programme. All opinions expressed in it, however, are entirely mine.

1 Robert Miles \& Malcolm Brown, Racism, London: Routledge, 2003, p105.

2 See Barry Cannon, 'April 2002: the myth of a united Venezuela', Bulletin of Latin American Research, 23 (3), 2004, pp 285-302.

3 Richard Gott, 'Latin America as a white settler society', Bulletin of Latin American Research, 26 (2), 2007, p 273; and Gregory Wilpert, Changing Venezuela by Taking Power, London: Verso, 2007, p 20.

4 Damarys Canache, 'Urban poor and political order', in Jennifer L McCoy \& David J Myers (eds), The Unraveling of Representative Democracy in Venezuela, Baltimore, MD: Johns Hopkins University Press, 2004, pp 44-46.

5 Kenneth Roberts, 'Social polarisation and the populist resurgence', in Steve Ellner \& Daniel Hellinger (eds), Venezuelan Politics in the Chávez Era: Class, Polarization and Conflict, Boulder, CO: Lynne Reinner, 2003, p 66.

6 Canache, 'Urban poor and political order', p 46.

7 Carlos Subero, 'Clases sociales tienen distinto candidato', El Universal (Seccíon Nacional y Política), 6 April 2000, at http://www.eluniversal.com/2000/04/06/06102AA.shtml, accessed 20 June 2003.

8 Datanalisis, Escenarios Julio, 2001, IV (3), 2003, p 21, Table 4.

9 Greenberg, Quinlan and Rosner, 'Venezuela, Resultados Estudio de Opinión Pública Nacional: Junio 23, 2004', at www.rnv.gov.ve/noticias/uploads/encuesta-greenberg-junio-2004.ppt, accessed 15 January 2008.

10 Evans/McDonough $\mathrm{Co} /$ Consultores 30.11, 'Clima Política Votantes Venezolanos: Presentación de resultados', 2007, at http://www.rethinkvenezuela.com/downloads/PRESENTACION_ENCUESTA_ NACIONAL_NOVIEMBRE_2007.pdf, accessed 15 January 2008.

11 Roberts, 'Social polarisation and the populist resurgence', p 55.

12 WR Wright, Café con Leche: Race, Class and National Image in Venezuela, Austin, TX: University of Texas Press, 1990.

13 Quinta Punto Fijo was the name of the house where the political agreement between the main parties, AD, COPEI and URD was drawn up after the 1958 coup against dictator Peréz Jimenez.

14 Miles \& Brown, Racism, p 37.

15 Ibid, pp 89-90.

$16 \mathrm{Ibid}, \mathrm{p} 11$.

17 Ibid, p 105.

18 Ibid, p 117.

19 Ibid, p 118.

20 Jesús Maria Herrera Salas, 'Ethnicity and evolution: the political economy of racism in Venezuela', Latin American Perspectives, 32, 2005, p 74. 
21 Judith Ewell, Venezuela: A Century of Change, Stanford, CA: Stanford University Press, 1984, p 14.

22 Patrick Wolfe, Settler Colonialism and the Transformation of Anthropology, London: Cassell, 1999, p 163, cited in Gott, 'Latin America as a white settler society', p 272.

23 Gott, 'Latin America as a white settler society', p 273.

24 Ibid.

25 Ibid.

26 Ibid.

27 Herrera Salas, 'Ethnicity and evolution', p 76.

28 Ibid, $\mathrm{p} 77$.

29 Ibid.

30 Oficina Central de Estadistica e Informatica/Programa Naciones Unidas para el Desarrollo (OCEA/ PNUD), Informe sobre Desarrollo Humano en Venezuela, 2000: Caminos para superar la probreza, Caracas: CDB Publicaciones, 2001, p 92.

31 Jun Ishibashi, 'Hacia una apertura del debate sobre el racismo en Venezuela: exclusión y inclusión esteriotipada de personas negras en los medios de comunicación', in Daniel Mato (ed), Politicas de identidades y diferencias sociales en tiempos de globalización, Caracas: FACES-UCV, 2003, p 34.

32 Ibid, p 48.

33 Ibid, p 49.

34 World Values Survey, 'Online Data Analysis, Venezuela-1996, 2000: Sociodemographics - Ethnic Description', at http://www.jdsurvey.net/bdasepjds/wvsevs/home.jsp?OWNER=WVS, accessed 15 January 2008.

35 Ewell, Venezuela.

36 Herrera Salas, 'Ethnicity and evolution'.

37 Fernando Coronil \& Julie Skurski, 'Dismembering and remembering the nation: the semantics of political violence in Venezuela', Comparative Studies in Society and History, 33 (2), 1991, p 326.

38 Ibid, p 328.

39 Margarita López-Maya, 'Venezuela after the Caracazo: forms of protest in a deinstitutionalized context', Bulletin of Latin American Studies, 21 (2), 2000, pp 199-219.

40 Ibid, pp 50-51.

41 For example, in 1992 unemployment stood at $7.1 \%$ as opposed to $6.9 \%$ in 1988 . Of total employment in $1991,59.5 \%$ was in the formal sector while $40.5 \%$ was in the informal sector, as opposed to $61.9 \%$ and $39.7 \%$ respectively in 1988 . Between 1988 and 1991 poverty increased from $46 \%$ to $68 \%$ and extreme poverty from $14 \%$ to $34 \%$. See E Lander, 'The impact of neoliberal adjustment in Venezuela, 1989-1993', Latin American Perspectives, 23 (3), 1996, pp 50-73.

42 MBR-200/Pirela Romero, Lt Col A MBR-200, El Arbol de las Tres Raíces, Valencia, Venezuela, 1994.

43 Ernesto Laclau, 'What's in a word?', in Francisco Panizza, Populism and the Mirror of Democracy, London: Verso, 2005, pp 324-329.

44 Ibid, p100.

45 Francisco Panizza, 'Introduction', in Panizza, Populism and the Mirror of Democracy, p 19.

46 Hugo Chávez Frías, A Dos Años del 4 de febrero, Yare, no publisher, 1994, p 3.

47 Hugo Chávez Frías, Seis discursos del Presidente Constitucional de Venezuela, Hugo Chávez Frías, Caracas: Ediciones de la Presidencia de la República, 2000, p 21.

48 Ibid, p 17.

49 Ibid, p 18.

$50 \mathrm{Ibid}, \mathrm{p} 23$.

51 Nicolas Kozloff, 'A real radical democracy: Hugo Chávez and the politics of race', October 2005, at www.venezuelanalysis.com/articles.php?artno $=1577$.

52 'President Chávez offers cheap oil to the poor of the United States', interview with President Chávez by Democracy Now!, at http://www.democracynow.org/2005/9/20/venezuelas_president_chavez_offers_ cheap_oil, accessed 15 January 2008.

53 Nestor Francia, Antichavismo y Estupidez Ilustrada, Caracas: Rayuela Taller de Ediciones, 2000, pp $109-111$.

54 E Gomez, 'Sólo la presión social puede liberar conciencias', El Universal, 13 February 2002, p 4.

55 Herrera Salas, 'Ethnicity and evolution', p 85.

56 Ibid, pp 82-87.

57 Luis Duno Gottberg, 'Mob outrages: reflections on the media construction of the masses in Venezuela (April 2000-January 2003)', Journal of Latin American Cultural Studies, 13 (1), 2004, p 120.

58 Ibid, p 124.

59 Ibid, p 115

$60 \mathrm{Ibid}, \mathrm{p} 131$

61 Wilpert, Changing Venezuela by Taking Power, p 20. 


\section{BARRY CANNON}

62 Patricia Marquez, 'Vacas flacas y odios gordos: la polarización en Venezuela', in Patricia Marquez \& Ramón Piñango (eds), Realidades y Nuevos Caminos en esta Venezuela, Caracas: Ediciones del Instituto de Estudios Superiores de Administración, 2005, quoted in Herrera Salas, 'Ethnicity and evolution', p 86.

63 Herrara Salas, 'Ethnicity and evolution'.

64 Norbis Mujica Chirinos \& Sorayda Rincón González, 'Caracterización de la política social y la política económica del actual gobierno venezolano: 1999-2004', Revista Venezolana de Economía y Ciencias Sociales, 12 (1), 2006, pp 31-57, at http://www.revele.com.ve/programas/indice/ria.php?id=13331\& rev=reveecciso, accessed 15 January 2008.

65 Mark Weisbrot, Luis Sandoval \& David Rosnick, Poverty Rates in Venezuela: Getting the Numbers Right, at http://www.cepr.net/index.php?option=com_content\&task=view\&id=61\&Itemid=8, accessed 15 January 2008.

66 Ibid, p 10.

67 Terry Gibbs, 'Business as unusual: what the Chávez era tells us about democracy under globalisation', Third World Quarterly, 27 (2), 2006, p 272.

68 Programa Venezolano de Educación-Acción en Derechos Humanos (PROVEA), Informe Anual 2004005, p18, at www.derechos.org, accessed 15 January 2008.

69 PROVEA, Informe Anual 2005-2006, pp 30-33, at www.derechos.org, accessed 15 January 2008.

70 Ibid, p 33.

71 PROVEA, Informe Anual 2006-2007, p 19, at www.derechos.org, accessed 15 January 2008. 